\title{
Analisis Kesalahan Peserta Didik Dalam Menyelesaikan Soal Matematika Pada Fungsi Komposisi Dan Fungsi Invers
}

\author{
Alfitrisni Yuliana Kolins', Wahyuningsih², Nurfitriah Safrudin ${ }^{3}$, Muhammad Epi Rusdin ${ }^{4}$ \\ 1,2,3 Program Studi Pendidikan Matematika, IKIP Muhammadiyah Maumere \\ ${ }^{4}$ Program Studi Pendidikan Fisika, IKIP Muhammadiyah Maumere \\ *alfitrisni98@gmail.com
}

\begin{abstract}
ABSTRAK
Dalam proses pembelajaran matematika, seringkali peserta didik mengalami kekeliruan atau kelalaian dalam penyelesaian soal yang diberikan baik soal latihan, tugas, ulangan maupun ujian. Penelitian ini bertujuan untuk mengetahui kesalahan peserta didik dalam menyelesaikan soal matematika pada fungsi komposisi dan fungsi invers di SMA Negeri 1 Maumere. Metode yang digunakan ialah kualitatif deskriptif, dengan subjek penelitian peserta didik X MIPA 4 yang berjumlah 34 orang yang dipilih berdasarkan teknik purposive sampling dimana subjek ini adalah subjek yang mendapat materi pada matematika wajib yaitu materi Fungsi Komposisi dan Fungsi Invers. Prosedur pengumpulan data diambil melalui pemberian soal tes dan wawancara kepada peserta didik. Analisis data meliputi reduksi data, penyajian data dan kesimpulan. Hasil penelitian ini dapat dikatakan bahwa kesalahan peserta didik dalam menyelesaikan soal matematika pada fungsi komposisi dan fungsi invers peserta didik berkemampuan tinggi, sedang dan rendah melakukan kesalahan yang sama yaitu kesalahan menggunakan data, kesalahan interpretasi bahasa dan kesalahan teknis.
\end{abstract}

Kata Kunci: Analisis Kesalahan, Fungsi Invers, Fungsi Komposisi

\begin{abstract}
In learning mathematics, students often experience mistakes or omissions in solving the questions given both the questions of practice, assignments, tests, and exams. This study aims to determine the student's errors mistakes in solving mathematical problems in the composition and inverse functions in SMA Negeri 1 Maumere. The method used is descriptive qualitative, with X MIPA 4 students' research subjects, amounting to 34 people who were selected based on purposive sampling technique where this subject who gets material on compulsory mathematics, namely the material composition function and inverse function. Data collection procedures are taken through the provision of test questions and interviews whit students. Data analysis includes data reduction, data presentation, and conclusions. This study results can be said that the student's errors in solving mathematical problems in the composition and inverse functions of high, medium, and low ability students make the same mistakes, namely errors in using data, language interpretation errors, and technical errors.
\end{abstract}

Key words: Composition Function, Error Analysis, Inverse Function

Received: 2020-07-13 ～～/ Accepted: 2020-08-25～/ Publised: 2020-11-01

\section{Pendahuluan}

Membentuk kemampuan dan potensi dalam diri manusia untuk menggunakan akal dan logika semaksimal mungkin dapat diperoleh melalui dunia pendidikan sebagai upaya untuk menciptakan masa depan yang kondusif dalam menghadapi masalah-masalah yang timbul (Susanti \& Lestari, 2019). Secara umum, pendidikan bertujuan untuk mencerdaskan dan mengembangkan kemampuan dalam diri para peserta didik. Ilmu pengetahuan dalam pendidikan yang menjadi dasar dalam ilmu pengetahuan lain salah satunya adalah matematika yang menjadi aspek pokok bidang studi yang berperan penting dalam pendidikan (Mursari, 2019). Pendidikan matematika merupakan ilmu dasar dalam semua bidang kehidupan manusia yang memerlukan otak kita sebagai kemampuan berpikir (Wulandari \& Resta, 2018). Matematika memiliki peranan penting pada pendidikan atau disiplin ilmu lain yang dikaitkan dan merupakan mata pelajaran yang dalam kegiatan pembelajarannya memerlukan tingkat 
pemahaman yang tinggi dan bukan hanya sekedar menghafal (Susanti \& Lestari, 2019).

Seringkali, peserta didik menganggap bahwa mata pelajaran yang sangat sulit adalah mata pelajaran matematika. (Sujoko \& Yustiana , 2017) mengatakan bahwasanya matematika sangat tidak disukai peserta didik karena dipandang sebagai mata pelajaran yang memiliki tingkat kesukaran yang tinggi dan cukup membosankan. Hal tersebut bisa menimbulkan perasaan takut sebelum peserta didik tersebut benar-benar mempelajari mata pelajaran matematika. Pada akhirnya akan tertanam dalam diri peserta didik bahwa pelajaran matematika itu sulit. Sehingga masalah tersebut bisa mempengaruhi dan menyebabkan peserta didik mengalami kesulitan dalam hal pemahaman konsep dan teorema matematika (Susanti \& Lestari, 2019). Sejalan dengan perkembangan mental peserta didik yang masih menganggap mata pelajaran matematika merupakan pelajaran yang sulit sehingga bisa berpengaruh terhadap ketertarikan dengan pelajaran matematika yang akan berdampak langsung terhaadap peserta didik dalam memahami logika dan konsep matematika, kesulitan dalam menyelesaikan masalah matematika, dan kurangnya dalam pemahaman pelajaran lain yang berkaitan dengan matematika (Dirgantoro, 2018).

Hasil observasi pelaksanaan magang di SMA Negeri 1 Maumere, diperoleh beberapa permasalahan matematika diantaranya adalah tingkat pemahaman peserta didik yang masih rendah karena matematika adalah mata pelajaran yang bersifat deduktif aksiomatik dan abstrak (Utami, 2017) yang dapat menimbulkan kesalahan ataupun kekeliruan peserta didik dalam menyelesaikan soal matematika. Kemudian, karakter setiap peserta didik yang berbeda-beda dan sifat peserta didik yang berbeda dalam menerima pelajaran matematika, sehingga tidak ada konsentrasi menerima pelajaran matematika. Selain itu, kurangnya kepedulian guru terhadap kesalahan ataupun kekeliruan yang dilakukan peserta didik dalam penyelesaian soal yang diberikan. Sehingga pada setiap kesalahan penyelesaian soal yang tidak diperbaiki akan dilakukan peserta didik secara berulang-ulang, baik itu kesalahan dalam menentukan rumus ataupun teorema dan prosedural dalam menyelesaikan soal sampai pada hasil jawaban soal.

Penjelasan kesalahan pada KBBI adalah suatu kelalaian yang dilakukan seseorang secara tidak sengaja dalam hal apapun. Kesalahan didefinisikan sebagai salah satu bentuk penyimpangan dari suatu fakta yang bersifat sistematis, konsisten yang dilakukan secara terus menerus dalam kurun waktu dan pada bagian tertentu (Agustia, Ndia, \& Ikman, 2016). (Agustiawan, Uno, \& Ismail, 2013) mengemukakan bahwa kesalahan adalah bentuk dari penyimpangan terhadap suatu hal yang sudah pasti atau sesuai fakta yang ada dan proses yang telah ditetapkan sebelumnya atau bentuk penyimpangan dari suatu hal yang kita harapkan. Menurut (Abdurrahman, 2012) mendefinisikan bahwa kekeliruan yang biasa terjadi dan dilakukan oleh anak berkesulitan dalam mempelajari matematika adalah pemahaman simbol matematika yang sangat rendah, nilai tempat, kekeliruan dalam menghitung, penggunaan proses yang keliru dan tulisan yang tidak terbaca. (Rofi'ah, Ansori, \& Mawaddah, 2019) menjelaskan bahwa kesalahan atau kekeliruan matematika yang dilakukan peserta didik adalah kurangnya kesiapan belajar terhadap definisi maupun konsep dan prosedur matematika yang baru, hanya mengambil langkah-langkah penyelesaian matematika yang lebih mudah, kesalahan yang dibuat memiliki pengertian tersendiri dan membuat kesalahan matematika yang beraturan.

Kesalahan dalam penyelesaian masalah matematika peserta didik terdiri dari beberapa aspek diantaranya: kesalahan memahami fakta-fakta, kesalahan dalam pemahaman konsep atau teorema, kesalahan melakukan operasi dan kesalahan dalam memahami prinsip-prinsip (Yensy, 2018). Kesalahan penyelesaian soal matematika peserta didik meliputi kesalahan 
konsep/teorema merupakan kekeliruan peserta didik untuk menentukan teorema dan rumus untuk penyelesaian masalah dalam soal. Kesalahan algoritma/prosedur merupakan ketidakhirarkian langkah dan kekeliruan memanipulasi aljabar dalam menyelesaikan soal. Kesalahan teknis merupakan kesalahan dalam melakukan perhitungan yang kurang tepat, (Nurjanatin, Sugondo, \& Manurung, 2017).

Fungsi komposisi adalah gabungan dari operasi pada dua fungsi $f(x)$ dan $g(x)$ sampai bisa diperoleh fungsi baru. Jika fungsi $f$ dan $g$ serta $R_{f} \cap D_{g} \neq \varnothing$ maka terdapat suatu fungsi komposisi $f$ dang(ditulis $g o f$ dan $g$ dibaca bundaran $f$ ) yang ditentukan dengan $h(x)=(g \circ f)(x)=g(f(x))$. Daerah asal fungsi komposisi $f$ dan $g$ adalah $D_{\text {gof }}=\left\{x \in D_{f} \mid f(x) \in D_{g}\right\}$, dimana $D_{f}=$ daerah asal (domain) fungsi $f ; D_{g}=$ daerah asal (domain) fungsi $g ; R_{f}=$ daerah hasil (range) fungsi $f ; R_{g}$ daerah hasil (range) fungsi $g$ (Miyanto, Ngapiningsih, \& Suparno, 2017).

Agar dapat memahami fungsi komposisi perhatikan gambar 1 berikut.

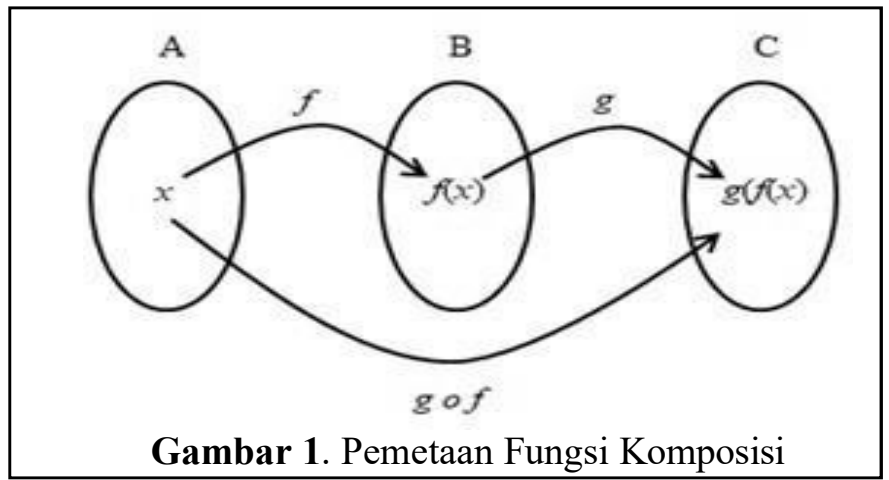

Dari gambar 1 di atas dapat diketahui bahwa:

Apabila $f: A \rightarrow B$ ditentukan dengan menggunakan rumus $y=f(x)$.

Apabila $g: B \rightarrow C$ ditentukan dengan menggunakan rumus $y=g(x)$.

Sehingga, akan diperoleh fungsi $g$ dan $f$ yaitu:

$h(x)=(g \circ f)(x)=g(f(x))$

Jika fungsi $f: A \rightarrow B$ dan dinyatakan dalam pasangan berurut $f=\{(x, y) \mid x \in A$ dan $x \in B\}$, maka invers fungsi $f$ (dilambangkan $f^{-1}$ ) adalah relasi yang memetakan $B$ ke $A$ dan dinyatakan dalam pasangan berurutan $f^{-1}=\{(y, x) \mid y \in B$ dan $x \in A\}$, (Miyanto, Ngapiningsih, \& Suparno, 2017). Invers fungsi $f$ juga dinyatakan dengan $f^{-1}$ seperti gambar 2 di bawah ini:

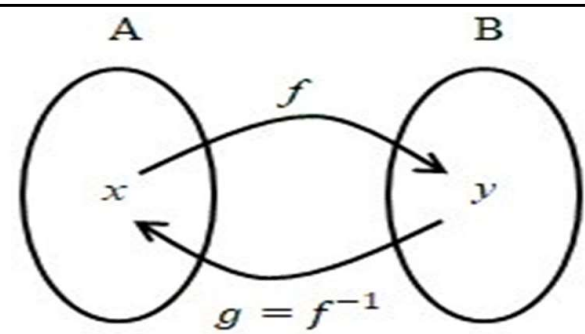

Gambar 2. Pemetaan Fungsi Invers 
Dalam fungsi invers ada rumus khusus seperti berikut ini, perhatikan tabel 1.

Tabel 1. Tabel Jenis Fungsi Invers

\begin{tabular}{lll}
\hline Jenis Fungsi & \multicolumn{1}{c}{$f(x)$} & \multicolumn{1}{c}{$f^{-1}(x)$} \\
\hline Fungsi linier & $f(x)=a x+b ; a \neq 0$ & $f^{-1}=\frac{x-b}{a} ; a \neq 0$ \\
Fungsi pecahan & $f(x)=\frac{a x+b}{c x+d} ; x \neq-\frac{d}{c}$ & $f^{-1}=\frac{-d x+b}{c x-a}$ \\
linier & $f(x)=\sqrt[n]{a x+b ; a \neq 0}$ & $f^{-1}=\frac{x^{n}-b}{a}$ \\
Fungsi & & \\
Irrasional & $f(x)=a x^{2} \pm b x+c ; a \neq 0$ & $f^{-1}(x)=\frac{-b \pm \sqrt{b^{2}-4 a(c-x)}}{2 a}, a \neq 0$ \\
Fungsi kuadrat & & $f^{-1}(x)={ }^{a} \log x$ \\
Fungsi & $f(x)=a^{x}$ & $f^{-1}(x)={ }^{a} \log x^{\frac{1}{c}}=\left(\frac{1}{c}\right)^{a} \log x$ \\
eksponen & $f(x)=a^{c x} ; a>0 \neq 1$ & $f^{-1}(x)=a^{x}$ \\
Fungsi & $f(x)={ }^{a} \log x$ & $f^{-1}(x)=\frac{a^{x}}{c}, c \neq 0$ \\
Logaritma & $f(x)={ }^{a} \log c x, a>0 \neq 1 ; c x>0$ & \\
&
\end{tabular}

Penelitian yang telah dilakukan menjelaskan bahwa kesalahan penyelesaian soal matematika peserta didik adalah kesalahan konsep, kesalahan menggunakan data, kesalahan interpretasi bahasa dan kesalahan penarikan kesimpulan (Rifai, 2012). Penelitian lainnya (Maratus Solihah, 2018) mengungkapkan bahwa kesalahan penyelesaian soal matematika peserta didik menyelesaikan soal cerita yaitu kesalahan yang terkait dengan kesalahan konsep, kesalahan penggunaan data, kesalahan interpretasi bahasa, kesalahan teknis dan kesalahan penyimpulan. Kesalahan peserta didik dalam menyelesaikan soal tersebut dapat menjadi salah satu upaya untuk mengetahui sejauh penguasaan materi oleh peserta didik, sehingga kesalahan peserta didik perlu dianalisis lebih lanjut agar memperoleh gambaran yang lebih rinci atas kesalahankesalahan peserta didik dalam menyelesaikan soal matematika (Aisyah, Hariyani, \& Dinullah, 2019) khususnya pada materi fungsi komposisi dan fungsi invers. Sehingga penelitian ini dapat memberikan masukan bagi guru matematika dalam peningkatan penyampaian materi dan prosedur penyelesaian soal yang lebih baik dan mendorong peserta didik dalam meningkatkan kemampuan belajarnya.

Penelitian yang telah dilakukan menjelaskan bahwa kesalahan penyelesaian soal matematika peserta didik adalah kesalahan konsep, kesalahan menggunakan data, kesalahan interpretasi bahasa dan kesalahan penarikan kesimpulan (Rifai, 2012). Penelitian lainnya (Maratus Solihah, 2018) mengungkapkan bahwa kesalahan penyelesaian soal matematika peserta didik menyelesaikan soal cerita yaitu kesalahan yang terkait dengan kesalahan konsep, kesalahan penggunaan data, kesalahan interpretasi bahasa, kesalahan teknis dan kesalahan penyimpulan. Kesalahan peserta didik dalam menyelesaikan soal tersebut dapat menjadi salah satu upaya untuk mengetahui sejauh penguasaan materi oleh peserta didik, sehingga kesalahan peserta didik perlu dianalisis lebih lanjut agar memperoleh gambaran yang lebih rinci atas kesalahan- 
kesalahan peserta didik dalam menyelesaikan soal matematika (Aisyah, Hariyani, \& Dinullah, 2019) khususnya pada materi fungsi komposisi dan fungsi invers. Sehingga penelitian ini dapat memberikan masukan bagi guru matematika dalam peningkatan penyampaian materi dan prosedur penyelesaian soal yang lebih baik dan mendorong peserta didik dalam meningkatkan kemampuan belajarnya.

\section{Metode Penelitian}

Penelitian ini dilakukan di SMA Negeri 1 Maumere, Kabupaten Sikka, Provinsi Nusa Tenggara Timur. Jenis penelitian ini adalah penelitian kulitatif dengan metode deskriptif kualitatif yang mendeskripsikan jenis-jenis kesalahan peserta didik dalam menyelesaikan soal matematika pada materi fungsi komposisi dan fungsi invers. Subjek penelitian ini adalah kelas X MIPA 4 yang berjumlah 34 peserta didik yang diperoleh berdasarkan teknik purposive sampling. Purposive sampling adalah teknik pengambilan sampel menggunakan pertimbangan tertentu. Subyek yang dipilih pada kelas X ini merupakan subyek yang mendapat materi pada Matematika Wajib mengenai Fungsi Komposisi dan Fungsi Invers. Prosedur pengumpulan data diambil melalui pemberian soal tes uraian sejumlah 6 soal yang sudah divalidasi oleh dosen ahli dan wawancara tidak terstruktur terhadap 6 orang peserta didik yang dipilih berdasarkan tingkat kemampuannya adalah dari hasil nilai yang diperoleh dari soal tes yang diberikan. Analisis data dilakukan meliputi reduksi data, penyajian, penarikan kesimpulan.

Berikut beberapa kategori atau jenis kesalahan dan indikator kesalahan dalam penyelesaian soal dapat dilihat pada tabel 2 (Romadiastri, 2012).

Tabel 2. Jenis-Jenis dan Indikator Analisis Kesalahan Peserta Didik

\begin{tabular}{|c|c|c|}
\hline No & $\begin{array}{l}\text { Jenis-Jenis } \\
\text { Kesalahan }\end{array}$ & Indikator Kesalahan \\
\hline 1. & $\begin{array}{l}\text { Kesalahan } \\
\text { Konsep }\end{array}$ & $\begin{array}{l}\text { a. Peserta didik tidak menentukan rumus dan teorema dalam } \\
\text { menjawab soal. } \\
\text { b. Teorema atau rumus yang digunakan oleh peserta didik tidak } \\
\text { sesuai dengan ketentuan rumus dan teorema yang berlaku pada soal }\end{array}$ \\
\hline 2. & $\begin{array}{l}\text { Kesalahan } \\
\text { menggunaka } \\
\text { n data. }\end{array}$ & $\begin{array}{l}\text { a. Peserta didik tidak menggunakan data yang harusnya digunakan. } \\
\text { b. Peserta didik salah memasukkan atau mensubtitusikan data ke } \\
\text { variabel. } \\
\text { c. Peserta didik menambah data yang harusnya tidak digunakan } \\
\text { dalam menjawab soal. }\end{array}$ \\
\hline 3. & $\begin{array}{l}\text { Kesalahan } \\
\text { interpretasi } \\
\text { bahasa. }\end{array}$ & $\begin{array}{l}\text { a. Peserta didik salah dalam menyatakan bahasa sehari-hari ke dalam } \\
\text { bahasa matematika. } \\
\text { b. Peserta didik salah menggunakan simbol-simbol ke dalam bahasa } \\
\text { matematika. }\end{array}$ \\
\hline 4. & $\begin{array}{l}\text { Kesalahan } \\
\text { teknis. }\end{array}$ & $\begin{array}{l}\text { a. Peserta didik salah dalam melakukan perhitungan atau komputasi. } \\
\text { b. Peserta didik salah dalam memanipulasi operasi aljabar. }\end{array}$ \\
\hline 5. & $\begin{array}{l}\text { Kesalahan } \\
\text { penarikan } \\
\text { kesimpulan. }\end{array}$ & $\begin{array}{l}\text { a. Peserta didik salah menyimpulkan jawaban tanpa alasan } \\
\text { pendukung yang tepat } \\
\text { b. Peserta didik salah menyimpulkan jawaban yang tidak sesuai } \\
\text { dengan penalaran logis. }\end{array}$ \\
\hline
\end{tabular}




\section{Hasil dan Pembahasan}

Tahap pertama yang dilakukan yaitu pemberian soal tes uraian sejumlah 6 soal pada pokok bahasan fungsi komposisi dan fungsi invers yang telah dipelajari sebelumnya oleh peserta didik dan soal tersebut adalah soal yang sudah divalidasi. Setelah tes dilaksanakan, diperiksa hasil jawaban peserta didik untuk diidentifikasi kesalahan yang dilakukan peserta didik. Berdasarkan hasil kemampuan perolehan nilai dari soal tes yang diberikan kepada 34 orang peserta didik kelas X MIPA 4, peserta didik dibagi dalam beberapa tingkat kemampuan peserta didik yaitu kemampuan tinggi, sedang dan rendah. Tahap kedua dalam penelitian ini, dilakukan wawancara tidak terstruktur kepada 6 orang peserta didik yang telah dipilih berdasarkan kelompok yang sudah ditentukan menurut tingkat kemampuan peserta didik. Wawancara ini bertujuan untuk memperdalam informasi tentang jenis kesalahan peserta didik dalam menjawab soal tersebut.

Hasil analisis kesalahan yang dilakukan, menunjukkan bahwa peserta didik yang memiliki kemampuan tinggi berjumlah 2 orang, kemampuan sedang berjumlah 2 orang dan kemampuan rendah berjumlah 2 orang dengan S1 Pada peserta didik yang berkemampuan tinggi, kesalahan yang dilakukan hanya satu kesalahan dari lima kategori kesalahan dalam menyelesaikan soal. Peserta didik berkemampuan sedang melakukan tiga kesalahan dari lima kategori kesalahan dalam menyelesaikan soal sedangkan pada peserta didik berkemampuan rendah melakukan lima kesalahan dari melakukan satu kesalahan dari 1 soal, SII melakukan tiga kesalahani 2 soal, SIII melakukan tiga kesalahan dari 2 soal, SIV melakukan tiga kesalahan dari 3 soal, SV melakukan empat kesalahan dari 5 soal, SVI melakukan lima kesalahan dari 6 soal.

Kesalahan-kesalahan tersebut dapat disajikan pada tabel 3 berikut.

Tabel 3. Jenis Kesalahan

\begin{tabular}{cccc}
\hline Subjek & $\begin{array}{c}\text { Kesalahan Nomor } \\
\text { Soal }\end{array}$ & Jenis Kesalahan & Kemampuan \\
\hline SI & 4 & $\mathrm{~K} 2$ & Tinggi \\
SII & 3 & $\mathrm{~K} 3, \mathrm{~K} 4$ & Tinggi \\
& 4 & $\mathrm{~K} 2$ & \\
SIII & 3 & $\mathrm{~K} 3, \mathrm{~K} 4$ & Sedang \\
& 4 & $\mathrm{~K} 2, \mathrm{~K} 4$ & \\
SIV & 2 & $\mathrm{~K} 2, \mathrm{~K} 2, \mathrm{~K} 4$ & Sedang \\
& 4 & $\mathrm{~K} 4$ & \\
SV & 6 & $\mathrm{~K} 2, \mathrm{~K} 4, \mathrm{~K} 5$ & \\
& 2 & $\mathrm{~K} 2, \mathrm{~K} 4$ & \\
& 3 & $\mathrm{~K} 2, \mathrm{~K} 4$ & \\
& 4 & $\mathrm{~K} 4$ & \\
& 5 & $\mathrm{~K} 1$ & Rendah \\
SVI & 6 & $\mathrm{~K} 2, \mathrm{~K} 4$ & \\
& 1 & $\mathrm{~K} 1, \mathrm{~K} 2, \mathrm{~K} 4$ & \\
& 2 & $\mathrm{~K} 1, \mathrm{~K} 2, \mathrm{~K} 4$ & \\
& 3 & $\mathrm{~K} 1, \mathrm{~K} 2, \mathrm{~K} 4$ & \\
& 4 & $\mathrm{~K} 1, \mathrm{~K} 2, \mathrm{~K} 4$ & \\
& 5 & & \\
& 6 & &
\end{tabular}


Keterangan:

K1 : Kesalahan Konsep

K2 : Kesalahan Menggunakan Data

K3 : Kesalahan Interprestasi Bahasa

K4 : Kesalahan Teknis

K5 : Kesalahan Penarikan Kesimpulan

Berdasarkan tabel 3, dapat dikatakan bahwa peserta didik yang memiliki kemampuan tinggi salah menyelesaikan soal pada nomor 3 dan 4 dengan melakukan 3 kesalahan dari 5 kategori kesalahan yaitu K2, K3 dan K4. Peserta didik yang memiliki kemampuan sedang salah menyelesaikan soal pada nomor 2, 3, 4 dan 6 dengan melakukan 4 kesalahan dari 5 kategori kesalahan yaitu K1, K2, K3 dan K4. Sedangkan peserta didik yang memiliki kemampuan rendah salah menyelesaikan semua soal dengan melakukan semua kesalahan dari kategori kesalahan yang ada dengan kesalahan adalah K1, K2, K3, K4 dan K5.

Setelah data direduksi, maka selanjutnya disajikan data beberapa kategori kesalahan berdasarkan hasil penyelesaian soal peserta didik dan data wawancara yang dilakukan untuk memperdalam informasi tentang jenis kesalahan peserta didik dalam menjawab soal tersebut. Berikut penyajian data beberapa subjek yang diambil mengenai ulasan kesalahan dalam menyelesaikan soal, yang mewakili semua kesalahan dari kategori kesalahan.

Gambar 3 berikut merupakan penyelesaian soal peserta didik pada nomor 1 dan kesalahan yang dilakukan adalah kesalahan konsep.

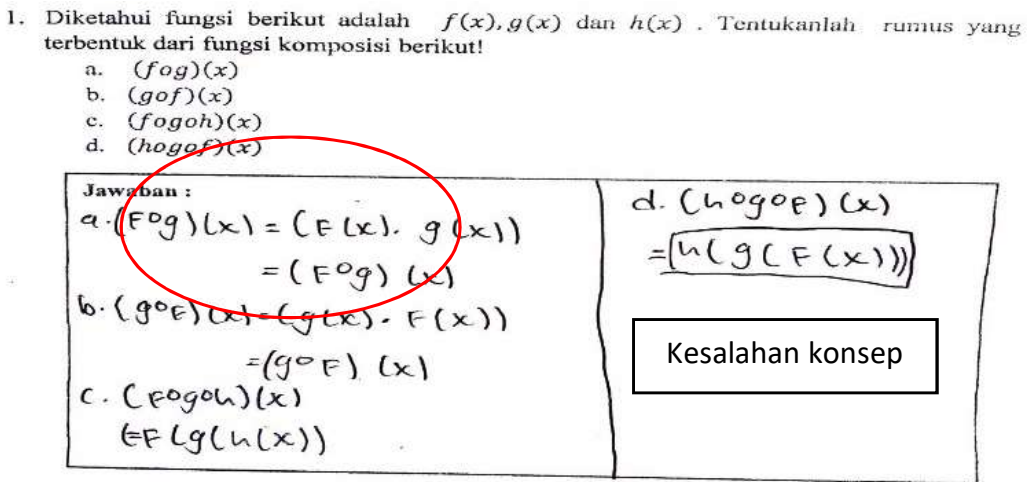

Gambar 3. Kesalahan Konsep

Berdasarkan gambar 3 kesalahan yang dilakukan peserta didik SVI yaitu kesalahan konsep dimana peserta didik langsung mengalikan kedua fungsi yaitu $f(x)$ dan $g(x)$ dalam penyelesaian soal pada obsen a dan $b$, dan hasil akhir jawaban sama dengan pertanyaan dari soal. Dari hasil wawancara dengan peserta didik SVI pada soal nomor 1, peserta didik SVI salah dalam menuliskan rumus atau konsep dari fungsi komposisi dikarenakan peserta didik hanya mengetaui rumus yang seperti pada nomor 1 .

Pada gambar 4 berikut merupakan peserta didik Subjek V yang melakukan kesalahan konsep dalam menyelesaikan soal pada nomor 2 . 
2. Jika diketahui fungsi komposisi dan fungsi berturut turut $(g \circ f)(x)=3 x^{2}-5 x+6$ dan $(g)(x)=x+6$. Tentukanlah nilai fungsi dari $(f)(-1)$

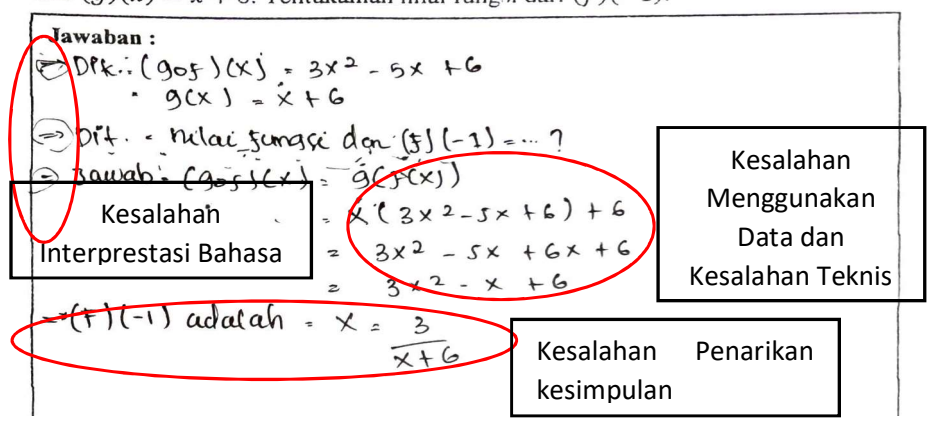

Gambar 4. kesalahan yang dilakukan Subjek V pada Nomor 2

Dari jawaban peserta didik SV pada Gambar 4, peserta didik salah dalam mensubtitusikan $f(x)$ ke fungsi $g(x)$. Sehingga peserta didik SV salah dalam melakukan perhitungan selanjutnya. Oleh karena itu hasil jawaban yang diperoleh masih salah. Kemudian peserta didik menambahkan simbol yang tidak dibutuhkan dalam penyelesaian soal. Dari hasil wawancara dengan peserta didik SV pada soal nomor 2, peserta didik SV salah dan keliru dalam menyelesaikan soal, kemudian salah dalam mengartikan simbol dan masih kurang memahami soal sehingga salah dalam melakukan operasi aljabar.

Penarikan kesimpulan pada penelitian ini adalah dengan menyimpulkan hasil uraian singkat penyelesaian soal matematika peserta didik dan data hasil wawancara berdasarkan penelitian yang dilakukan Yulia Romadiastri. Sehingga pada peneltian ini ditemukan lima jenis kesalahan yang dilakukan peserta didik dalam menyelesaikan soal fungsi komposisi dan fungsi invers diantaranya kesalahan konsep, kesalahan menggunakan data, kesalahan interpretasi bahasa, kesalahan teknis dan kesalahan penarikan kesimpulan. Kesalahan konsep yang ditemukan diantaranya adalah peserta didik salah menentukan dan menuliskan rumus yang tidak sesuai dengan berlakunya rumus dalam menjawab soal. Seperti pada rumus fungsi komposisi ialah $(g \circ f)(x)=g(f(x))$ namun ada peserta didik yang menuliskan rumus fungsi komposisi ialah $(g \circ f)(x)=(g(x) . f(x))$ dan peserta didik lupa menuliskan rumus terlebih dahulu sehingga salah dalam mensubtitusikan fungsi pada variabel $\mathrm{x}$.

Berdasarkan hasil analisis yang diperoleh, dapat dikatakan bahwa sebagian besar dari peserta didik baik peserta didik yang berkemampuan tinggi, sedang dan rendah melakukan kesalahan yang sama pada kesalahan menggunakan data. Kesalahan menggunakan data yang ditemukan diantaranya adalah peserta didik tidak menggunakan data yang harus digunakan dalam menjawab soal. Seperti pada nomor 4, yaitu nilai dari $f^{-1}(q)=-1$. Sebagian besar dari peserta didik tidak ada yang memasukan nilai $f^{-1}(q)=-1$ ke dalam penyelesaian soal. Namun ada juga yang keliru dan langsung mensubtitusikan -1 ke variabel $q$. Kemudian peserta didik salah dalam mensubtitusikan fungsi ke variabel. Seperti terdapat peserta didik yang salah mensubtitusikan nilai $f x$ dan $g(x)$ dengan mengalikan kedua fungsi tersebut dan peserta didik tidak menuliskan simbol operasi bilangan yang dibutuhkan pada penyelesaian soal. Kemudian kesalahan interpretasi bahasa yang ditemukan dari penelitian ini diantaranya adalah peserta didik salah dalam mengartikan simbol sehingga menambahkan simbol-simbol yang tidak dibutuhkan dalam menjawab soal. simbol yang mereka tulis adalah $*, / /,, \Rightarrow$. Simbol $*$ yang diartikan peserta didik ialah kesimpulan akhir dari soal. Simbol // diartikan peserta didik 
sebagai hasil dari jawaban akhir. Simbol $\gg$ diartikan oleh peserta didik sebagai lanjutan dari penyelesaian soal. Simbol $\Rightarrow$ diartikan oleh peserta didik sebagai sama dengan.

Pada kesalahan teknis, dapat dilihat berdasarkan hasil reduksi dan penyajian data sebagian besar dilakukan oleh peserta didik berkemampuan tinggi, sedang dan rendah dan kesalahan teknis yang ditemukan dari penelitian ini peserta didik salah dalam melakukan perhitungan atau operasi dalam menyelesaikan soal. Seperti dalam menentukan invers peserta didik kurang teliti sehingga salah dalam menginverskan sebuah fungsi $g(x)=3 x-13$. Peserta didik menjawab inversnya adalah $g^{-1}(x)=\frac{x-13}{3}$, namun seharusnya invers dari $g(x)=3 x-13$ adalah $g^{-1}(x)=\frac{x+13}{3}$. Sehingga pada proses penyelesaian selanjutnya salah dan menyebabkan jawaban akhirnya juga salah. Selain itu ada juga yang salah dalam melakukan peritungan operasi aljabar $(g \circ f)(x)=(2 x-1)^{2}+4(2 x-1)-5$. Seharusnya hasil penyelesaian berikutnya adalah $(g \circ f)(x)=\left(4 x^{2}-4 x+1\right)+(8 x-4)-5$ tetapi yang dijawab peserta didik adalah $(g \circ f)(x)=4 x^{2}-4 x+2-8 x+4-5$. Sesuai dengan analisis, kesalahan penarikan kesimpulan ini hanya dilakukan oleh peserta didik berkemampuan rendah. Kesalahan penarikan kesimpulan yang ditemukan dari penelitian ini adalah peserta didik melakukan penyimpulan akhir dari soal tidak sesuai dengan jawaban soal menggunakan simbol yang tidak sesuai untuk kesimpulan.

Hasil penelitian sejalan dengan penelitian yang dilakukan (Cahyani, 2016) dan (Utami, 2017). Mei Yovika Indah Cahyani mengatakan bahwasanya dari kedua subjek melaksanakan kesalahan yang berbeda-beda. Adapun subjek I melaksanakan kesalahan di tahap membaca, transformasi, keterampilan proses dan penyelesaian akhir dari sebuah jawaban. Sementara subjek II mengalami kesalahan pada semua tahap. Selanjutnya, Arum Setya Utami mengatakan bahwasanya jenis kesalahan lain yang dilaksanakan peserta didik adalah kesalahan dalam melaporkan masalah, tentukan kesalahan apa yang ditanyakan dari suatu masalah, pahami informasi kesalahan suatu masalah, dan tidak cermat dalam menghitung.

\section{Simpulan}

Berdasarkan hasil analisis maka ditemukan beberapa kesalahan penyelesaian soal peserta didik pada fungsi komposisi dan fungsi invers. Sehingga, dapat dikatakan bahwa kesalahan penyelesaian soal untuk fungsi komposisi dan fungsi invers baik peserta didik yang memiliki kemampuan tinggi, sedang dan rendah melakukan kesalahan yang sama pada kesalahan menggunakan data, kesalahan interpretasi bahasa dan kesalahan teknis. Oleh karena itu, merujuk dari hasil penelitian ini diharapkan guru lebih memastikan agar peserta didik telah menguasai operasi aljabar dengan baik dan bisa mengetahui penggunaan simbol-simbol dalam matematika agar kesalahan menggunakan data, kesalahan interpretasi bahasa dan kesalahan teknis dapat diminimalkan.

\section{Daftar Pustaka}

Aisyah, F. N., Hariyani, S., \& Dinullah, R. N. (2019). Analisis Kesalahan Penyelesaian Soal Cerita Berdasarkan Kriteria Watson. Jurnal Review Pembelajaran Matematika, 4(1), 11 22.

Cahyani, M. Y. (2016). Analisis Kesalahan Peserta Didik Dalam Menyelesaikan Soal Matematika Materi Fungsi Komposisi dan Fungsi Invers Kelas XI IPA SMAN 10 Malang Menggunakan Prosedur Newman. Skripsi, Universitas Negeri Malang, Program Studi Pendidikan Matematika. 
Dirgantoro, K. P. (2018). Kompetensi Guru Matematika dalam Mengembangkan Kompetensi Matematis Siswa. Jurnal Pendidikan dan Kebudayaan, 8(2), 157-166.

Miyanto, Ngapiningsih, \& Suparno. (2017). PR Matematika untuk SMA/MA/SMK/MAK Kelas $X$ Semester 2. Klaten, Indonesia: PT. Intan Pariwara.

Mursari, C. (2019). Deskripsi Kemampuan Berpikir Kritis Matematis dan Kemandirian Belajar Siswa Ditinjau dari Gaya Belajar. AlphaMath(Journal of Mathematics Education), 5(2), 48-56.

Nurjanatin, I., Sugondo, G., \& Manurung, M. M. (2017). Analisis Kesalahan Peserta Didik dalam Menyelesaikan Soal Cerita pada Materi Luas Permukaan Balok di Kelas VIII-F Semester II SMP Negeri 2 Jayapura. Jurnal Ilmiah Matematika dan Pembelajarannya, 2(1), 22-31.

Rofi'ah, N., Ansori, H., \& Mawaddah, S. (2019). Analisis Kesalahan Siswa dalam Menyelesaikan Soal Cerita Matematika Berdasarkan Langkah Penyelesaian Polya. EDUMAT:Jurnal Pendidikan Matematika, 7(2), 120-129.

Romadiastri, Y. (2012). Analisis Kesalahan Mahasiswa Matematika dalam Menyelesaikan Soal-Soal Logika. Jurnal PHENOMENON, 2(1), 75-93.

Sujoko, W., \& Yustiana, A. (2017, 11). Analisis Kesulitan Siswa Kelas XI Menyelesaikan Soal Fungsi Komposisi dan Fungsi Invers di SMA Al-Washliyah Tanjung Morawa Tahun Ajaran 2015/2016.

Susanti, B., \& Lestari, Y. A. (2019). Analisis Kesulitan Siswa Kelas XI Dalam Menyelesaikan Soal Fungsi Komposisi dan Fungsi Invers di SMK Al-Ikhsan Batujajar. Jurnal On Education, 01(03), 446-459.

Utami, A. S. (2017). Analisis Kesalahan Siswa Dalam Menyelesaikan Soal Cerita Pokok Bahasan Komposisi Fungsi di SMK Bakti Purwokerto. AlphaMath(Journal of Mathematics Education, 3(2), 48-56.

Wulandari, T., \& Resta, E. L. (2018). Analisis Kesalahan Siswa Dalam Menyelesaikan Soal Pada Materi Lingkaran. Jurnal Pendidikan Tambusai, 2(6), 1693-1697.

Yensy, N. A. (2018). Diagnosis Kesalahan Mahasiswa Dalam Menyelesaikan Soal Perhitungan Peluang Pada Matakuliah Statistika Matematika. Jurnal Pendidikan Eksakta, 2(4), 146. 